\title{
Research on the Impact of Customer Perceived Value of Haidilao Hot Pot on Consumer Behavior
}

\author{
Qiong $\mathrm{LI}^{1}$, Anlan LI \\ Department of Economic Management, Wuhan Huaxia University of Technology, \\ Wuhan, P.R.China
}

\begin{abstract}
The paper takes Haidilao Hot Pot as the object through the collection of first-hand data, and analyzes the relationship between customer perceived value in functional value, emotional value, convenience value and social value on consumer behavior. Through factor analysis and variance analysis, it can be found that the four dimensions of customer perceived value have a significant positive impact on customer satisfaction, and customer satisfaction also has a significant positive impact on customer loyalty. Among them, functional value is the most important and obvious factor influencing customer purchasing decisions. The paper collects relevant data to complete the relevant content in the case of a global epidemic, hoping to provide certain guidance for the market-oriented adjustment of catering companies that are most affected by the epidemic.
\end{abstract}

Keyword. Catering; customer satisfaction; customer perceived value; consumer behavior; customer loyalty

\section{Introduction}

With the changes in the economic background of the times and the arrival of the experience economy era, what people buy is no longer the product itself but their expectations. Consumers hope to realize certain customer value in the transaction process, and the essence of customer value is customer perception, that is, customers' subjective perception of the interaction process and results of a certain enterprise.

Foreign scholar Zeithaml (1990) believes that when companies design, create, and provide value for customers, they should start from customer orientation, and take customer perception of value as the decisive factor[1]. Kolter (1969) and Levy proposed at the first time that "customer satisfaction depends on perceived value", which has attracted widespread attention abroad[2]. Then McDougall et al. (2000) further demonstrated the important role of customer value in business management in the research center of typical service industries, and concluded that there is a positive correlation between customer perceived value and customer satisfaction[3]. Li Man

\footnotetext{
${ }^{1}$ Corresponding Author, Qiong LI, Department of Economic Management, Wuhan Huaxia University of Technology, Wuhan, P.R.China; E-mail: liqiong913@163.com; This paper was the research on the Influence Mechanism of the EWOM Information Type and Quality on the Consumer's purchase intention in the cultural consumption industry - Hubei film industry as an example (No. 18G143) by the General Humanities and Social Sciences Projects of the Ministry of Education 2018.
} 
(2018) believes that quality, the role of brand, and the importance of customer value to the perception of customer experience are closely linked[4]. At the same time, related research shows that customer perceived value not only directly affects customer behavior, but also indirectly affects customer behavior through customer satisfaction. Zeithaml's research model points out that customer perceived value is an intermediate variable that affects quality and customer behavior, that is, customer Perceived value has a direct impact on customer behavior[5]. Domestic scholars Bai Changhong (2001) believe that customers always pursue maximum value, and then slowly modify their expected value from the accumulation of consumer experience, which indirectly affects customer satisfaction and behavioral tendencies[6]. The paper takes Haidilao, a well-known domestic catering company as the object, and encountered the global new crown epidemic during the research process. The collected data can better reflect the impact of customer perceived value on consumer behavior, and the customer perception of the catering industry in a specific market environment. The shaping of value has good theoretical and practical significance.

\section{Theoretical models and indicators}

\subsection{Model framework}

Claes For nell summarized the research results of customer satisfaction. CSI is referred to as the Customer Satisfaction Index for short, and the American Customer Satisfaction Index (ACIS) is also based on this[7].

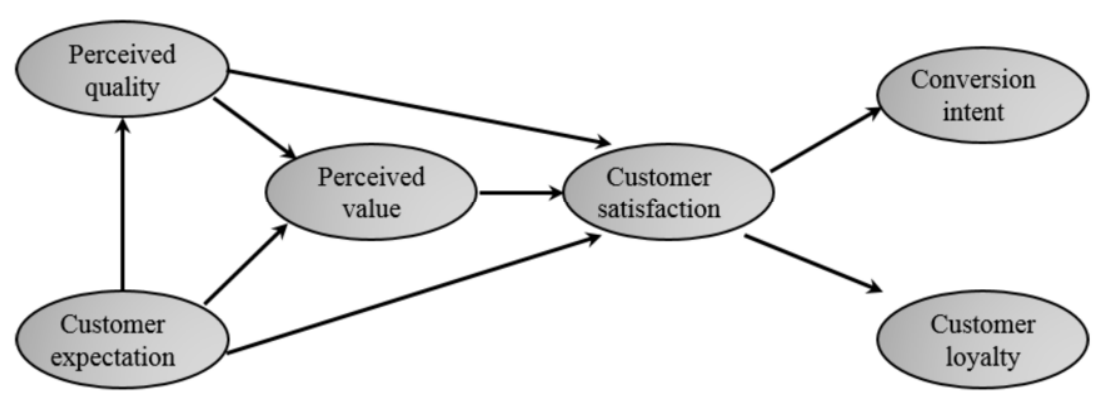

Figure 2.1 U.S. Customer Satisfaction Index Model Diagram(ACIS)

The perceived value of Haidilao studied in this article is that consumers recognize and choose the products of catering companies, and explain the perceived value of the value of catering products. Specifically, perceived value is the measurement of customers between perceived benefits and perceived costs[8]. Early scholars also believed that perceived value includes utilitarianism and hedonism. Since then, researchers have continuously deepened and expanded the research content of perceived value[9].

Therefore, this article proposes the following hypotheses: Hypothesis 1: Customer perceived value has a significant positive impact on customer satisfaction; Hypothesis 2: Customer satisfaction has a significant positive impact on customer loyalty; Hypothesis 3: Customer perceived value has a significant positive impact on customer loyalty. 


\subsection{Model variable definition and measurement indicators}

\subsubsection{Customer Perceived Value}

The core factor of customer perceived value is the measurement between perceived benefit and perceived effort. The early definition of customer loyalty believes that only by excluding accidental factors, some deviation factors caused by convenient purchase and consumption, and the special case of customer multi-brand loyalty, continuous consumption purchase behavior can be used as a measure of customer loyalty. Customer satisfaction is that the actual expectations of customers are higher than the expectations of the customers themselves. This article makes corresponding evaluations of customer satisfaction from the following three aspects:

(1)The customer's reaction to their product or service evaluation during the consumption process; (2)Customers' buying experience of products or services exceeds their expectations; (3)Customer's own consumption experience, which is consumption evaluation

\subsection{2 measurement standard}

Table 2.1 Items for measuring customer perceived value

\begin{tabular}{|c|c|}
\hline Measurement & Measurement item \\
\hline \multirow{12}{*}{ customer perceived value } & A01 Different feelings when entering a restaurant \\
\hline & A02 A sense of intimacy from the restaurant staff \\
\hline & A03 The pleasure of ordering and checkout speed \\
\hline & A04 The comfort level of the store environment \\
\hline & A05 Ease of parking \\
\hline & A06 Location is close/multiple points \\
\hline & A07 Reasonable price \\
\hline & A08 Food safety \\
\hline & A09 Complete food variety \\
\hline & A10 Service from staff in time \\
\hline & A11 Clean tableware \\
\hline & A12 Delicious dishes \\
\hline Functional value & A4; A11; A $12 ;$ A 13 \\
\hline Emotional value & A10; A2; A1 \\
\hline Convenience value & A3; A5; A6; A7 \\
\hline Social value & A8; A9 \\
\hline
\end{tabular}

Table 2.2 Measurement items of customer loyalty

\begin{tabular}{|l|l|}
\hline Measurement & \multicolumn{1}{c|}{ Measurement items } \\
\hline \multirow{2}{*}{ customer loyalty } & B1 I often eat in this restaurant \\
\cline { 2 - 3 } & B2 Would recommend this restaurant to a friend \\
\cline { 2 - 3 } & $\begin{array}{l}\text { B3 Compared with other restaurants, Haidilao's products and } \\
\text { services are my first choice }\end{array}$ \\
\cline { 2 - 3 } & B4 Will continue to visit Haidilao \\
\hline
\end{tabular}


Table 2.3 Measurement items of customer satisfaction

\begin{tabular}{|c|c|}
\hline Measurement & Measurement items \\
\hline \multirow[t]{4}{*}{ customer satisfaction } & $\begin{array}{l}\text { C1 Haidilao products and services are excellent } \\
\text { value for money }\end{array}$ \\
\hline & C2 Haidilao's corporate image is good \\
\hline & $\begin{array}{l}\text { C3 Haidilao's services and products often exceed } \\
\text { my imagination }\end{array}$ \\
\hline & C4 Overall very satisfied with Haidilao \\
\hline
\end{tabular}

\section{Questionnaire design and data analysis}

\subsection{Data collection and collation}

1) Selection of samples. The subject of this questionnaire is the customers of Haidilao, a branch of Haidilao Chain Enterprise in Wuhan City, Hubei Province.

2) This question is to study the impact of customer perceived value on consumer behavior and the impact of the CIS model based on customer perception. In the actual survey process, 200 questionnaires were issued and 179 valid questionnaires were collected. The recovery rate was $89.5 \%$.

\subsection{Data analysis}

\subsubsection{Questionnaire reliability analysis}

It can be seen from Table 3.1 that the reliability coefficient value is 0.784 , which is greater than 0.5 , which indicates that the reliability of the research data is relatively high and suitable for questionnaire analysis.

\subsubsection{Questionnaire validity analysis}

Table 3.2 shows the KMO sample measurement and Bartley sphere test results of customer perceived value.

\subsection{3 factor analysis}

Through analyzing the five dimensions of customer perceived value, the reliability is high.

Table 3.1 Trust level analysis

\begin{tabular}{cccc}
\hline Name & Measured variable & acoefficient deleted & Cronbach's $\alpha$ coefficient \\
\hline $\begin{array}{c}\text { Customer Perceived } \\
\text { Value }\end{array}$ & 0.764 & 0.898 & 0.784 \\
Customer loyalty & 0.743 & 0.842 & \\
$\quad \begin{array}{c}\text { Customer } \\
\text { Satisfaction }\end{array}$ & 0.634 & 0.753 & \\
\hline
\end{tabular}


Table 3.2 KMO and Bartlett test results

\begin{tabular}{|l|c|r|}
\hline \multicolumn{2}{|c|}{ KMO sampling is an appropriate measure } & .762 \\
\hline Barrtlett's sphere test & Chi-square read above & 457.641 \\
\hline & Degree of freedom & 21 \\
\hline & Significance & .000 \\
\hline
\end{tabular}

Table 3.3 Customer Perceived Value Factor Analysis Results

\begin{tabular}{|c|c|c|c|c|}
\hline \multicolumn{5}{|c|}{ Component } \\
\hline & $\begin{array}{l}\text { Emotional } \\
\text { value }\end{array}$ & $\begin{array}{l}\text { Convenience } \\
\text { value }\end{array}$ & $\begin{array}{l}\text { Functional } \\
\text { value }\end{array}$ & $\begin{array}{l}\text { Social } \\
\text { value }\end{array}$ \\
\hline $\begin{array}{l}\text { A01 Different feelings when entering a } \\
\text { restaurant }\end{array}$ & .743 & .204 & .052 & .324 \\
\hline $\begin{array}{l}\text { A02 A sense of intimacy from the } \\
\text { restaurant staff }\end{array}$ & .735 & .279 & .173 & .192 \\
\hline $\begin{array}{l}\text { A03 The pleasure of ordering and } \\
\text { checkout speed }\end{array}$ & .114 & .529 & .413 & .308 \\
\hline $\begin{array}{l}\text { A04 The comfort level of the store } \\
\text { environment }\end{array}$ & .058 & .406 & .688 & .145 \\
\hline A05 Ease of parking & .247 & .698 & -.034 & .008 \\
\hline A06 Location is close/multiple points & .153 & .799 & .157 & -.045 \\
\hline A07 Reasonable price & .324 & .634 & .104 & .208 \\
\hline A08 Food safety & .123 & .040 & .013 & .584 \\
\hline A09 Complete food variety & .668 & .072 & .014 & .865 \\
\hline A10 Service from staff in time & .253 & .023 & .014 & .067 \\
\hline A11 Clean tableware & .447 & .012 & .083 & -.106 \\
\hline A12 Delicious dishes & -.198 & .084 & .678 & .420 \\
\hline Cronbach & .727 & .702 & .829 & .835 \\
\hline
\end{tabular}

Table 3.4 Variance contribution

\begin{tabular}{|l|c|c|c|c|}
\hline \multicolumn{1}{|c|}{ Factor naming } & $\begin{array}{c}\text { Functional } \\
\text { perceived } \\
\text { value }\end{array}$ & $\begin{array}{c}\text { Convenience } \\
\text { perception } \\
\text { value }\end{array}$ & $\begin{array}{c}\text { Sentimental } \\
\text { value }\end{array}$ & $\begin{array}{c}\text { Socially } \\
\text { perceived } \\
\text { value }\end{array}$ \\
\hline Variance contribution & $30.17 \%$ & $11.023 \%$ & $8.87 \%$ & $8.67 \%$ \\
\hline $\begin{array}{l}\text { Cumulative variance } \\
\text { contribution }\end{array}$ & $58.733 \%$ & & & \\
\hline
\end{tabular}

\subsection{4 regression analysis}

(1)This section discusses the impact of several dimensions that affect perceived value on customer satisfaction from the perspective of customer perceived value. It uses customer satisfaction as the calibration standard and the predictive variable is the regression analysis of customer perceived value. 
Table 3.5 Overall model parameters

\begin{tabular}{|r|r|r|r|r|}
\hline Model & R & R.Square & $\begin{array}{r}\text { Adjuest R } \\
\text { Square }\end{array}$ & $\begin{array}{r}\text { Std.Error of } \\
\text { the Estimate }\end{array}$ \\
\hline 1 & $.886(\mathrm{a})$ & .773 & .783 & .960 \\
\hline
\end{tabular}

Table 3.6 Regression coefficients and t test

\begin{tabular}{|c|c|c|c|c|c|}
\hline \multirow[t]{2}{*}{ Mode } & \multicolumn{2}{|c|}{ Unstandardized Coefficients } & \multirow{2}{*}{$\begin{array}{l}\text { Standardized } \\
\text { Coefficients } \\
\text { Beta } \\
\end{array}$} & \multirow[t]{2}{*}{$\mathrm{t}$} & \multirow[t]{2}{*}{ Sig } \\
\hline & $\mathrm{B}$ & Std.Error & & & \\
\hline $\mathrm{I}($ Constant $)$ & -.263 & 645 & & -.408 & .673 \\
\hline $\begin{array}{l}\text { Functional } \\
\text { value }\end{array}$ & .865 & .042 & .683 & 21.254 & .000 \\
\hline $\begin{array}{l}\text { Convenience } \\
\text { value }\end{array}$ & .358 & .032 & .337 & 10.438 & .001 \\
\hline $\begin{array}{l}\text { Emotional } \\
\text { value }\end{array}$ & .108 & .032 & .117 & 25.622 & .004 \\
\hline Social value & .082 & .052 & .094 & .10 .511 & .005 \\
\hline
\end{tabular}

It can be seen from the statistical results of 3.5 that all dimensions of customer perceived value can be used as influencing factors of customer satisfaction.

The regression equation is:

$\mathrm{CS}=0.683 \mathrm{~F}+0.117 \mathrm{C}+0.091 \mathrm{E}+0.337 \mathrm{~S}$

Through regression analysis, we know that all dimensions of perceived value have an impact on perceived satisfaction. Hypothesis 1 has been verified. Among them, functional value has the most obvious impact and emotional function is the weakest.

(2)This section discusses the impact of customer satisfaction on customer loyalty from the perspective of customer perceived value. It uses customer satisfaction as the school standard and the predictive variable for the regression analysis of customer loyalty value.

Table 3.7 Overall model parameters

\begin{tabular}{|r|r|r|l|r|}
\hline Model & R & R.Square & $\begin{array}{l}\text { Adjuest } \\
\text { R Square }\end{array}$ & $\begin{array}{r}\text { Std.Error of } \\
\text { the Estimate }\end{array}$ \\
\hline 1 & $.926(\mathrm{a})$ & .858 & .856 & .790 \\
\hline
\end{tabular}

Table 3.8 Regression coefficient and t test

\begin{tabular}{|c|c|c|c|c|c|}
\hline \multirow[t]{2}{*}{ Mode } & \multicolumn{2}{|c|}{ Unstandardized Coefficients } & \multirow{2}{*}{$\begin{array}{l}\text { Standardized } \\
\text { Coefficients } \\
\text { Beta }\end{array}$} & \multirow[t]{2}{*}{$\mathrm{t}$} & \multirow[t]{2}{*}{ Sig } \\
\hline & B & Std.Error & & & \\
\hline I(Constant) & -.263 & .645 & & 3.252 & .001 \\
\hline $\begin{array}{l}\text { Customer } \\
\text { Satisfaction }\end{array}$ & .924 & .023 & .925 & 42.074 & .000 \\
\hline
\end{tabular}

From 3.7 statistics, it is concluded that customer satisfaction can be used as an explanatory variable for loyalty. The regression equation is: $\mathrm{CL}=0.925 \mathrm{CS}$ 
Through regression analysis, we know that customer satisfaction has a positive effect on customer loyalty. Hypothesis 2 is verified.

This section discusses the impact on customer loyalty from several dimensions of customer perception. The study uses perception as a variable and loyalty is the school standard for regression analysis.

Table 3.9 Overall model parameters

\begin{tabular}{|r|r|r|r|r|}
\hline Model & R & R.Square & Adjuest R Square & $\begin{array}{r}\text { Std.Error of } \\
\text { the Estimate }\end{array}$ \\
\hline 1 & $.897(\mathrm{a})$ & .803 & .801 & .930 \\
\hline
\end{tabular}

Table 3.10 Regression coefficient and t test

\begin{tabular}{|c|c|c|c|c|c|}
\hline \multirow[t]{2}{*}{ Mode } & \multicolumn{2}{|c|}{$\begin{array}{l}\text { Unstandardized } \\
\text { Coefficients }\end{array}$} & \multirow{2}{*}{$\begin{array}{l}\text { Standardized } \\
\text { Coefficients } \\
\text { Beta }\end{array}$} & \multirow[t]{2}{*}{$\mathrm{t}$} & \multirow[t]{2}{*}{ Sig } \\
\hline & $\mathrm{B}$ & Std.Error & & & \\
\hline I(Constant) & -1.762 & .623 & & -2.843 & .005 \\
\hline Functional value & .812 & .040 & .643 & 20.254 & .000 \\
\hline Convenience value & .298 & .034 & .280 & 9.438 & .000 \\
\hline Emotional value & .125 & .032 & .118 & 3.922 & .000 \\
\hline Social value & .147 & .055 & .079 & 2.611 & .004 \\
\hline
\end{tabular}

It can be seen from the statistical results of 3.9 that all dimensions of customer perceived value can be used as influencing factors of customer loyalty. Hypothesis 3 is verified.

The regression equation is: $\mathrm{CL}=0.643 \mathrm{~F}+0.280 \mathrm{C}+0.118 \mathrm{E}+0.379 \mathrm{~S}+\mathrm{i}(\mathrm{i}$ is a constant $)$

Through regression analysis, it is known that loyalty has an impact on the various dimensions of perceived value, of which functional value has the most obvious impact and social function is the weakest.

\section{Conclusion and Outlook}

\subsection{Conclusion study}

Based on survey interviews, this paper uses factor analysis to demonstrate the relationship between customer perceived value and customer satisfaction and customer loyalty. It is found that the four dimensions of customer perceived value have a significant impact on customer satisfaction, with functional value being the most significant. Emotional value is the weakest. It can be seen that to a certain extent, the perceived value of the function of the company determines the purchase decision and recommendation behavior of customers. Then, starting from several dimensions of customer perception, and using perception as the variable loyalty as the school standard, the regression analysis found that the various dimensions of customer perception value have an impact on customer loyalty. Among them, functional value has the most obvious influence, and social functional value is the weakest. Companies in a competitive industry try their best to satisfy customers first. If the company's products 
and services are too general and do not make customers feel that they have obtained a higher consumption value, it will not be easy to attract customers to buy again.

\subsection{Management advice}

\section{1) Service Packaging Strategy}

Through research, we also know that perceived value is positively related to service satisfaction. The quality of the catering environment and the concept of good catering are all helpful to enhance the perceived value of consumers.

2) Provide personalized services to meet the needs of different customers

In the era of perception economy, catering companies should give full play to their specialties and apply "personalized service marketing strategies" so as not only to meet the needs of different customers, but also to enhance the perceived value of customers。 3) Improve customer satisfaction

Adjust product strategy in time, meet customer needs in a targeted manner, improve service quality, and increase satisfaction.

4) Deliver to consumers with high-quality products and high-quality services

It is not only necessary to improve the quality of products to convey a good emotional impression to consumers, but also to give consumers the best quality and best services and products to become the leader of the enterprise.

5) Propose strategies to maintain customer loyalty

Reasonably use the enterprise system to create consumer loyalty to the enterprise, establish consumer target groups, establish differentiated service marketing, and provide customers with high service quality.

\section{References}

[1] Zeithaml V.Parasuraman A, Berry. Delivering quality service, balancing customer perceptions and expectations[M]. New York: The Free Press,1990:30-32.

[2] Kolter,P.and Levy,Broadening The Concept of Marketing into Nonprofit Organizations[J],Journal of Marketing,1969(33):10-15.

[3] McDougall,S.,Curry,M.B.\&Curry,M.Exploring the effects of icon characteristics on user performance:The role of concreteness,complexity and distinctiveness[J]. Journal of Experimental Psychology: Applied,2000,6,291-306.

[4] Li Man, A Brief Analysis of the Relationship between Customer Perceived Value and Perceived Quality, Brand Image, and Customer Experience[J], Productivity Research, 2018, 11(2): 36-39

[5] Zeithaml,Valarie A.Consumer Perceptions of Price, Quality, and Value:A Means-End Model and Synthesis of Evidence[J]. Journal of Marketing, 1998,(3):16-254

[6] Bai Changhong, Western Customer Value Research and Its Practical Enlightenment[J], Nankai Management Review, 2001, (2): 72-74.

[7] Chen Jun, Chen Xinlong, Sun Yimin, Xin Leyao, Yu Zhouyuan. Research on Haidilao Restaurant Service Marketing Strategy [J]. Journal of Shanghai University (Social Science Edition), 2021:3-5.

[8] Zhong Kai, Zhang Chuanqing. Research on Consumer Perceived Value on Online Purchasing[D]. Wuhan: Zhongnan University of Economics and Law, 2017.

[9] Zeithaml.Consumer Perceptions of Price Quality and Value: A Means. Model ald Synthesis of Evidenee[J]. Joumal of Marketing, 1988, 52(3): 2-22. 